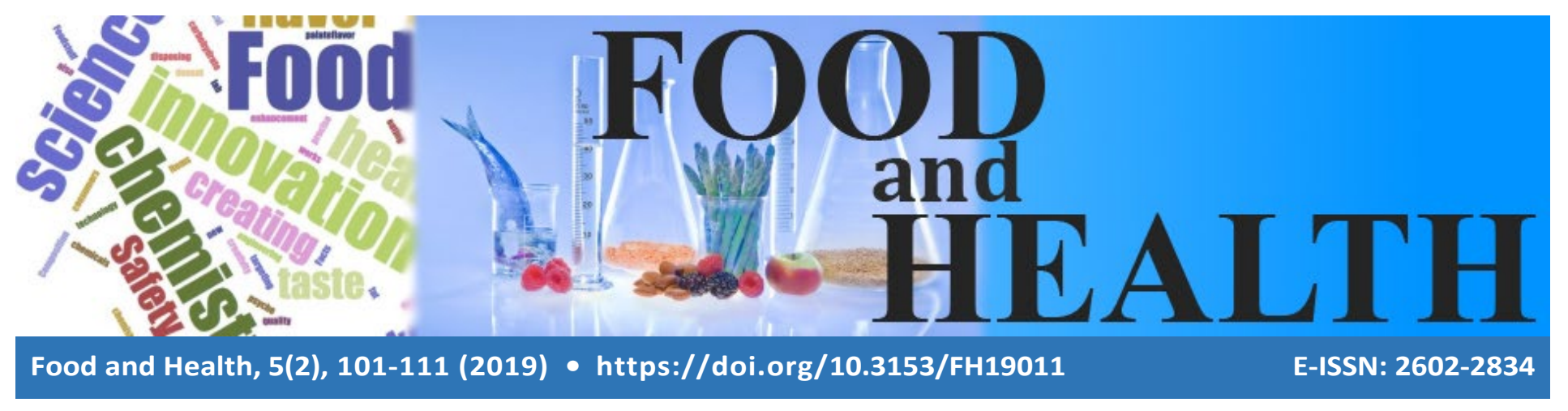

Research Article

\title{
NUTRITION-SOCIO-ECONOMIC STATUS RELATIONS EFFECT ON THE PHYSICAL DEVELOPMENT OF PRESCHOOL CHILDREN
}

\author{
Halime Selen ${ }^{\mathbb{D}}$, Aziz Aksoy (i)
}

Cite this article as:

Selen, H., Aksoy, A. (2019). Nutrition-socio-economic status relations effect on the physical development of preschool children. Food and Health, 5(2), 101-111. https://doi.org/10.3153/FH19011

Bitlis Eren University, School of Health, Department of Nutrition and Dietetics, Bitlis, Turkey

ORCID IDs of the authors: H.S. 0000-0002-3705-0875 A.A. 0000-0002-9683-6691

Submitted: 20.07 .2018

Accepted: 23.09 .2018

Published online: 28.11.2018

Correspondence:

Aziz AKSOY

E-mail: aksoy aziz@hotmail.com

(c) Copyright 2019 by ScientificWebJournals Available online at http://jifhs.scientificwebjournals.com

\section{ABSTRACT}

This study was conducted to question the socio-economic and educational status of preschool 4-6years old children and their families living in Bitlis and its counties; and also, to examine the effects of these variables on the nutrition and physical development status of children. A total of 960 students, 479 boys and 481 girls, aged between 4-6, who were attending preschools in Bitlis and its counties were included in the study. There was a significant difference $(P<0.05)$ between the BMI values of the children and the educational status of their parents; however, there was a very weak correlation between these values (mother $(r=0.163)$, father $(r=0.121$. When the total daily sleep durations and the BMIs of the children were compared, it was determined that there was a significant difference $(P<0.05)$ and a relation at a moderate severity $(\mathrm{r}=0.54)$. It was determined that the nutrition and physical development status of the children was related with the socio-economic and educational levels of the parents with a weak correlation and with a positive and very high correlation with the consumption of some food groups.

Keywords: Preschool feeding, Physical development, Socio-Economic status, Nutrition, BMI 


\section{Introduction}

Healthy nutrition in childhood means covering all the energy and nutritional requirements to provide and sustain a healthy life for children in terms of growth and development. Healthy eating habits in childhood ensure that children have a body structure that is appropriate for the genetic burden of a human in adulthood period (Shloim et al., 2015; Yalvaç et al., 2008). The consumption of healthy foods by young children is essential to provide normal growth and development with children and to prevent a variety of nutrition-related health problems (Aktaş and Angın, 2011). Today, almost all of the parents try hard to raise their children in the best possible way. The inadequacy of financial aids, the social family structure, the educational status, the financial acquisitions of the families, the elementary family structure, regional and local developments, social disasters (Acharya et al., 2015) (i.e. fires, wars, terrorism and migrations), the position of the residential area in relation to intensive settlement areas, poverty, underdevelopment, rapid population growth, rapid and uncontrolled and unplanned structures in dangerous areas, destruction or misuse of the environment, destruction of green spaces, ignorance and lack of education and all similar factors affect life itself and, of course, mostly children in the first place.

According to the analyses in the 2002 Health Report of the World Health Organization, it was reported that the poverty rates in all regions was increasing as the rate of low-weight births increased (Hashemian-Nejad et al., 2014; Özmert et al., 2005) and the weight of $27 \%$ of the world's under-fiveyear-old children was low compared to their age and that most of them lived in developing countries. Children who experience nutritional deficiencies in such countries are at a serious risk due to problems like malnutrition, vitamin-mineral deficiency (Hwalla et al., 2017), childhood deaths, fever diseases, diarrhea, frequent infectious diseases, decreased learning ability in children, stopping of the mental development, growth and physical development deficiencies and similar health problems (Prado and Dewey, 2014; Uauy et al., 2008).

On the one hand, children with nutritional deficiencies try to adapt to hunger and slow growth; and on the other hand, the risk of getting sick due to bodily wasting also increases.
There are nutrient groups which are necessary to be provided with healthy nutrition, and the nutrient groups to be consumed by preschool children, who are also the study group, are as follows (Auestad et al., 2015; Ekinci, 2018). Scientists have classified in five groups of nutrients (TUBER, 2015). Quantities of nutrients in these groups were determined and daily nutrition plans were made. Food groups which are necessary to be provided with healthy nutrition and food groups to be consumed by preschool children also, food groups and their peculiarities are the key concepts for nutrition education activities in preschool education (Angin et al., 2015). Nutrition shows itself in physical development as well as by affecting all kinds of developmental and behavioral stages. The direct relationship with BMI, height and weight is the most important indicator of the physical development (Aksoy et al., 2017). In general, physical development refers to the physical development of an individual as age grows from the prenatal period time of birth. Physical development is described as the development of organs that form the body such as increase in height, weight gain, development of bones and teeth, muscles, brain, nerves, digestion, circulation, respiration and excretion systems and the development of sensory organs (Garipagaoğlu and Özgüneş, 2008). Especially in this study, the subject that is emphasized in physical development will be the BMI values, which are calculated together with height and weight according to nutrition status. In recent years, there has been an increase in the prevalence of obesity that is associated with increases in BMI values, which is also the case in the whole world, and the prevalence is also increasing in children (Tam and Çakır, 2012). In general terms, obesity is the desired level of body weight being over the height of the body as a result of the excessive increase in the rate of lean mass to body fat mass when daily received energy is more than the consumed energy (WHO, 1995). In our country, obesity was also more common in family members with moderate and high-income levels (Kondolot et al., 2011) 
Physical Development and Body Mass Index (BMI) Percentile Values in Children

One of the most reliable criteria to evaluate the health status of both children and adults and to measure physical development is the age-related BMI (Aksoy and Selen, 2018). The BMI is obtained by dividing the body weight $(\mathrm{kg})$ of the individual by the square of the height $\left(\mathrm{m}^{2}\right)\left(\mathrm{kg} / \mathrm{m}^{2}\right)(\mathrm{WHO}$, 1995; WHO, 2000). BMI values corresponding to the percent of a group percentile by the age values of the children created with information compiled by Turkish researchers for Turkey in 2008 are also given in Table 1.

According to the above chart, percentage intervals that correspond to the weight classification category according to BMI percentiles created for the children by the World Health Organization are as in Table 2 below.

Children with a percentile range below $5 \%$ are classified as wasting, those between $5 \%$ and $85 \%$ are normal or healthy, those between $85 \%$ and $95 \%$ are fat, and those above $95 \%$ are classified as obese (Kondolot et al., 2011).

The city of Bitlis has borders with Van, Siirt, Batman, Muş and Ağrı, and is located in the Eastern Anatolian Region
(Demirtaş, 2008). According to SEGE-2011 data (SEGE, 2013) while Turkey's most developed provinces are located in the Marmara Region, and in western and coastal areas; the poorly- developed cities are located in the Eastern and Southeastern Anatolian Regions; and according to the report, Bitlis ranks the $76^{\text {th }}$ in terms of socio-economic development among the 81 provinces. Socioeconomic wasting gives rise to differences in terms of quality of life, education, social life, lifestyle, and social status; and brings deficiencies or differences in terms of nutrition, which is a permanent part of our lives.

The purpose of this study is to determine the nutritional status of children between 4-6 years old who go to preschool classes in Bitlis city center and 6 counties (Tatvan, Ahlat, Adilcevaz, Hizan, Güroymak, Mutki), which differ from each other in terms of education and development levels depending on the socio-economic situation; and also, to reveal the effects of these variables on the physical development of children. Similar studies have not been done on children before in the province and districts of Bitlis

Table 1. BMI values corresponding to the percentile by age for Turkish children between 4-6 years of age (TBSA, 2010)

\begin{tabular}{|c|c|c|c|c|c|c|c|c|c|c|c|c|c|c|}
\hline \multicolumn{15}{|c|}{ Smoothed age specific BMI for Turkish Boys and Girls (4-6 years of age) } \\
\hline \multicolumn{7}{|c|}{ Percentile Values for Boys } & & \multicolumn{7}{|c|}{ Percentile Values for Girls } \\
\hline 5 & 15 & 25 & $\mathbf{5 0}$ & 75 & 85 & 95 & Age & 5 & 15 & 25 & 50 & 75 & 85 & 95 \\
\hline 13.7 & 14.4 & 14.8 & 15.7 & 16.7 & 17.3 & 18.4 & 4 & 13.6 & 14.2 & 14.6 & 15.4 & 16.4 & 17.0 & 18.1 \\
\hline 13.6 & 14.2 & 14.7 & 15.6 & 16.6 & 17.2 & 18.4 & 4.5 & 13.5 & 14.2 & 14.6 & 15.4 & 16.5 & 17.1 & 18.2 \\
\hline 13.5 & 14.2 & 14.6 & 15.5 & 16.5 & 17.1 & 18.3 & 5 & 13.4 & 14.1 & 14.5 & 15.4 & 16.5 & 17.2 & 18.5 \\
\hline 13.4 & 14.1 & 14.5 & 15.4 & 16.5 & 17.1 & 18.4 & 5.5 & 13.4 & 14.0 & 14.5 & 15.5 & 16.6 & 17.3 & 18.8 \\
\hline 13.4 & 14.1 & 14.5 & 15.4 & 16.5 & 17.2 & 18.5 & 6 & 13.3 & 14.0 & 14.5 & 15.5 & 16.7 & 17.5 & 19.1 \\
\hline
\end{tabular}

Table 2. Classification of children's percentile values by weight status category according to the WHO (WHO, 2006)

\begin{tabular}{|c|c|}
\hline Weight Status Category & Percentage Interval \\
\hline Wasting & $<5$ \\
\hline Normal or Healthy & $5 \leq \mathrm{BMI}<85$ \\
\hline Overweight & $85 \leq \mathrm{BMI}<95$ \\
\hline Obese & $95 \leq \mathrm{BMI}$ \\
\hline
\end{tabular}




\section{Materials and Methods}

\section{Materials}

This study is a descriptive and cross-sectional qualitative study. The study was carried out with a total of 960 children (479 Girls (Female) and 481 Boys (Male) who attended preschools in Bitlis/Center and 6 counties (Tatvan, Ahlat, Adilcevaz, Hizan, Güroymak, Mutki) in 2018. The Questionnaire Model was used in the present study. A questionnaire consisting of 40 questions was applied. The questionnaire prepared by examining the literature was composed of three parts (TBSA, 2010), the questionnaire consisted of three parts. The data to determine the nutrient consumption frequency consisted of a 5-Point Likert Scale as "Always"; "Often", "Sometimes", "Rarely", "None". In the first part, there were questions on determining the information about the students and their families; in the second part, there were questions on determining the eating habits of the students; and in the third part, there were questions on determining the frequency of food consumption. Data were collected by face to face interviews with parents of children in school

\section{Methods}

The height measurements of the children were made by using the Harpenden Stadiometer (ADE/Hamburg, MZ10020) ultrasonic height measurement unit with an accuracy of 0.1 $\mathrm{cm}$ sensitivity, as the individual was standing parallel to the ground with nothing to affect the measurement, with light clothing; and shoes removed; the weight of the individuals was measured with the InBody230 (MW160) Bioelectrical Impedance Body Analyzer device. After the measurements of height and weight were made, questionnaires were answered by interviewing the parents of the students in a faceto-face manner. All ethical principles, which were included in the Helsinki European Human Rights Declaration, were obeyed on a basis of voluntariness.

The Independent Variables were; gender, age, place of residence, consumed food, demographic information of the parents, monthly expenditures of the children, and monthly income of the families, education and working status of the parents, and social security status of the family.

The Dependent Variables were; children's physical development.

\section{Statistical Analysis}

Using the SPSS Statistics 20.0 Package Program; the ChiSquare (single sample chi-square test), Mann- Whitney U, Test was employed to determine whether the observed values corresponding to the expected values; Non-Parametric and the Spearman Rank Correlation Coefficient Test Analysis was used to determine the direction of the relation between the variables. A level of $\mathrm{P}<0.05$ was considered to be statistically significant in evaluating the obtained results.

\section{Ethical Principles}

The study protocol was approved by Bitlis Eren University, Ethical Principles and Ethics Committee decision dated 13.12.2017 and with the number 2017/12-V.

\section{Results and Discussion}

Findings on Children's Age, Gender and Counties Resided

A total of $49.9 \%$ (479) of the children who participated in the study were girls; and $50.1 \%$ (481) of them were male. 106 of the participants $(54 \mathrm{~F}, 52 \mathrm{M})$ were 4 years old, 163 $(91 \mathrm{~F}, 72 \mathrm{M})$ were 4.5 years, $248(138 \mathrm{~F}, 110 \mathrm{M})$ were 5 years old, $328(152 \mathrm{~F}, 176 \mathrm{M})$ were 5.5 years old and $115(44 \mathrm{~F}$, $71 \mathrm{M}$ ) were 6 years old. The distribution of the children according to the counties was as follows; Bitlis/Center 168 $(90 \mathrm{~F}+78 \mathrm{M})$, Hizan $143 \quad(75 \mathrm{~F}+68 \mathrm{M})$, Güroymak 133 $(61 \mathrm{~F}+72 \mathrm{M}), \quad$ Mutki $134(72 \mathrm{~F}+62 \mathrm{M})$, Tatvan 140 $(62 \mathrm{~F}+78 \mathrm{M})$, Ahlat $121(61 \mathrm{~F}+60 \mathrm{M})$, Adilcevaz 121 $(60 \mathrm{~F}+61 \mathrm{M})$ children (Table 3$)$.

\section{Findings on the BMI, Gender and Age of the Children}

It was determined that a total of $12.9 \%$ (62) of the girls were wasting; $71.0 \%$ (340) were normal, 9.0\% (43) were fat, $7.1 \%$ (34) were obese; $13.5 \%$ (65) of the boys were wasting, $67.6 \%$ (325) were normal, $13.1 \%$ (63) were fat, 5.8\% (28) were obese; and the BMI values of the girls showed a distribution that was similar to each other.

When we look at the children's BMI distributions according to age, the distribution is similar in proportion to the participation rate. In the light of the present data, a statistical analysis was made which revealed that there was no significant difference $(\mathrm{P}>0.05)$ between age and gender and the BMI of the children (Table 3 ). 
Table 3. The BMI percentile distribution of the participating children according to the counties they live

\begin{tabular}{|c|c|c|c|c|c|c|c|c|}
\hline & \multicolumn{9}{|c|}{ District Center of Lived } & \\
\hline Child BMI & Bitlis & Hizan & Guroymak & Mutki & Tatvan & Ahlat & Adilcevaz & Total \\
\hline Wasting & 12 & 16 & 24 & 36 & 15 & 19 & 5 & 127 \\
\hline Normal & 124 & 106 & 85 & 88 & 94 & 82 & 86 & 665 \\
\hline Overweight & 22 & 12 & 12 & 5 & 23 & 11 & 21 & 106 \\
\hline Obese & 10 & 10 & 14 & 3 & 7 & 9 & 9 & 62 \\
\hline Total & 168 & 144 & 135 & 132 & 139 & 121 & 121 & 960 \\
\hline
\end{tabular}

Table 4. The BMI percentile distribution of the participating children according to age

\begin{tabular}{|c|c|c|c|c|c|c|}
\hline & \multicolumn{7}{|c|}{ Age } & \\
\hline Child BMI & $\mathbf{4}$ & $\mathbf{4 . 5}$ & $\mathbf{5}$ & $\mathbf{5 . 5}$ & $\mathbf{6}$ & Total \\
\hline Wasting & 12 & 24 & 34 & 41 & 16 & 127 \\
\hline Normal & 69 & 122 & 178 & 221 & 75 & 665 \\
\hline Overweight & 13 & 11 & 23 & 42 & 17 & 106 \\
\hline Obese & 12 & 6 & 13 & 24 & 7 & 62 \\
\hline Total & 106 & 163 & 248 & 328 & 115 & 960 \\
\hline
\end{tabular}

Findings on the BMI of the Children and the BMI of the Parents of the Children

A total of 960 mothers and 960 fathers participated in the study, and the BMI values of a total of 1920 participants were measured. According to the Obesity Classification of the BMU value that was determined by the WHO for adults (Forno et al., 2018), the rate of the $1^{\text {st }}, 2^{\text {nd }}$, and $3^{\text {rd }}$ degree fat participants was $13.6 \%$ (262) (this percentage may be accepted as low when the nearly $20 \%$ obesity average in our country is considered); the rate of those who were slightly fat was $43.1 \%$ (828), normal 38,6\% (742), acceptable 3.5\% (67), wasting $1.1 \%(21)$.

When the BMI of the children and that of the parents were compared, it was determined that there was a parallel increase in the number of obese children depending on the obesity status of the mothers, the BMI of the children and the BMI of the mothers. It was also observed that there was a significant difference at a statistically significant level $(P<0.05)$. No statistically significant differences were determined between the percentile values of the BMI values of the fathers and the BMI values of the children $(P>0.05)$.

Findings on the Children's BMI and the Total Monthly Income of Their Families, Monthly Expenditure of the Children and on the Inhabited Counties Resided

When the monthly income levels of the families of the children were compared, it was determined that $42.3 \%$ (406) of them were between 500 and 1609 TL; 15.9\% (153) were between 1610 and 2499 TL; $15.9 \%$ (153) were between 2500 and 3499 TL; 10.2\% (98) were between 3500 and 4449 TL; and $15.7 \%$ (150) were over 4500 TL monthly incomes. The income levels of most of the families were at or below the Official Minimum Wage.

When we look at the data that children marked as monthly spending, it was determined that $40.4 \%$ (389) of the children spend less than $100 \mathrm{TL}$, which is a very high rate; while $20.5 \%$ (196) spend 400 TL or more. $39.1 \%$ (375) this increase in the monthly expenditure on children suggests that they do not comply with the socio-economic indicators of the province. A statistically significant difference $(\mathrm{P}<0.05)$ was found between the monthly expenditures of the children and the percentile values of BMI, but the relationship between them was found to be very wasting $(\mathrm{r}=0.160)$. There was a significant difference $(P<0.05)$ in the statistical analysis between the monthly incomes of the children and the percentile values of the BMIs and the percentile values based on BMIs of the children according to the BMI category classification.

Families with low income levels were mostly found in Mutki and Hizan, while families with higher incomes were found in the counties of Bitlis/Center and Tatvan. The increase in the number of fat and obese children were found to be significant $(P<0.05)$ but showed a poor correlation 
$(\mathrm{r}=0.166)$ in the regions where the income increased and the parents were in the upper level status.

\section{Findings on How the Children Travel to Schools and on Their BMI Values}

In the data related to how the children traveled to schools, the students stated that $67 \%$ (643) walked to the school; $33 \%$ (317) traveled to school with service buses or private vehicles. When these data and the travel styles of the children to schools and their BMI values were associated with each other, it was determined that there were no significant differences between these variables and obesity in children $(P>0.05)$.

\section{Findings on the BMI and Educational Status of Their Parents}

When the educational status of the mothers was examined, it was determined that $15 \%$ (144) of the participants were literate; 49,7\% (478) were primary school graduates; $18,6 \%$ (178) were high school graduates; $16,7 \%$ (160) were university graduates; and 4,6\% (42) of the fathers were literate; $26,4 \%$ (254) were primary school graduates, 32,1\% (309) were high school graduates, $37,9 \%$ (355) were university graduates. When the BMI values of the children and the educational status of the parents were compared, it was determined that there was a significant difference $(P<0.05)$; and as the educational status of the parents increased, the number of the fat and obese children also increased. However, the correlation of these values (mothers' educational status $(\mathrm{r}=0,163)$, fathers' educational status $(\mathrm{r}=1,121)$ was found to be very wasting.

\section{Findings on the BMI values of the Children and the Social Security of Their Families}

When the BMI of the children and the social security status of the families were compared, it was determined that there was a significant difference $(P<0.05)$. However, the relation between them was found to be very wasting $(r=0,096)$. It is considered that this situation is related to the income status of the families and the educational levels of the parents.

Findings on the BMI of the Children and the Professions of the Parents

When the BMI of the children and the professions of the parents were compared, it was determined that there was a significant difference $(P<0.05)$; and the children of families who had high-level income (2.500.00 TL and over) were more inclined to be fat and obese. However, the relation between them was found to be very little and might be ignored $(\mathrm{r}=0.001)$.
Findings on the BMI of the Children, the Working Status of the Parents and the Number of Children in Families

When the number of siblings was questioned in the families who were included in the study, it was determined that $8.9 \%$ (86) had one, 35.7\% (343) had two, 29.3\% (282) had three, $15.2 \%$ (146) had four, 5.5\% (53) had five, $5.2 \% 50$ ) had six siblings. When the findings on the total number of children in families and their BMI values were examined, no significant difference was found when the BMI values were compared with those of the siblings $(P>0.05)$. The number of children may have varied according to the age of the parents and the duration of their marriages.

When the working status of the mothers was examined, it was determined that $10.6 \%$ (101) did not work, and $89.4 \%$ (859) worked. When the working status of the fathers were questioned, it was determined that $0.8 \%$ (7) did not work; and $99.2 \%$ (859) worked. There was no significant difference $(P>0.05)$ when children's BMI and mothers' and fathers' working status were compared.

\section{Findings on the BMI of the Children and the Daily Sleep Hours}

It was observed that there was a significant difference $(P<0.05)$ when the BMI and total sleeping hours of the children were compared; and fatness and obesity increased in children who had increased sleep durations. A moderately severe relation was detected between the BMI and sleep durations of the children $(\mathrm{r}=0.54)$ (Table 5).

\section{Findings on Meal Intake of the Children}

There was no significant difference $(P>0.05)$ between the 3 main meals (breakfast, lunch, dinner) and 3 intermediate meals (brunch, afternoon, night) consumption frequency $(P>0.05)$ according to the income levels of the families and the BMI values of the children (Table 6).

Findings on the Consumption of Some Nutrient Groups by Children

While no significant differences were detected between the total monthly incomes of the families and the BMI of the children and consumption of chocolate, pastries, biscuits, pudding, ice cream, nuts, crisps, popcorn, cokes, drink powders, sweets and candies, sandwich, milk, ayran, yogurt, cheese, fruit and vegetables, fruit yogurt, grissini, melba toast, oats, cornflakes, which are prepared at home, sweets, melba toast, oat, cornflakes, herbal teas, coffee, tea, readymade juice, meat, fish, chicken, turkey, egg and legumes $(P>0.05)$; a significant difference was determined between the consumption of fruit yogurt, pizza, hamburger, sausage, salami, etc. $(P<0.05)$ (Table 7). 
Table 5. The BMI percentile distribution of the preschool children according to their daily sleeping durations

\begin{tabular}{|c|c|c|c|c|c|c|c|c|c|}
\hline & \multicolumn{7}{|c|}{ Daily Sleep Time (Hours) } & \\
\hline Child BMI & $\mathbf{6}$ & $\mathbf{7}$ & $\mathbf{8}$ & $\mathbf{9}$ & $\mathbf{1 0}$ & $\mathbf{1 1}$ & $\mathbf{1 2}$ & $\mathbf{1 3}$ & Total \\
\hline Wasting & 0 & 2 & 28 & 34 & 47 & 6 & 10 & 28 & 127 \\
\hline Normal & 2 & 18 & 86 & 171 & 292 & 47 & 47 & 86 & 665 \\
\hline Overweight & 0 & 1 & 15 & 24 & 36 & 17 & 13 & 15 & 106 \\
\hline Obese & 0 & 2 & 12 & 12 & 35 & 1 & 0 & 12 & 62 \\
\hline Total & 2 & 23 & 141 & 241 & 410 & 71 & 70 & 141 & 960 \\
\hline
\end{tabular}

Table 6. The frequency of daily meal intake of the participating children

\begin{tabular}{|c|c|c|c|c|c|c|c|c|c|c|}
\hline \multirow{2}{*}{ The food menu } & \multicolumn{2}{|c|}{ Always } & \multicolumn{2}{c|}{ Often } & \multicolumn{2}{c|}{ Sometimes } & \multicolumn{2}{c|}{ Rarely } & \multicolumn{2}{c|}{ None } \\
\cline { 2 - 12 } & $\mathbf{n}$ & $\mathbf{\%}$ & $\mathbf{n}$ & $\mathbf{\%}$ & $\mathbf{n}$ & $\mathbf{\%}$ & $\mathbf{n}$ & $\mathbf{\%}$ & $\mathbf{n}$ & $\mathbf{\%}$ \\
\hline Breakfast & 792 & 82.50 & 53 & 5.52 & 89 & 9.27 & 19 & 1.97 & 7 & 0.72 \\
\hline Mid-Morning Meal & 81 & 8.43 & 53 & 5.52 & 244 & 25.41 & 120 & 12.50 & 462 & 48.12 \\
\hline Lunch & 780 & 81.25 & 82 & 8.54 & 80 & 8.33 & 12 & 1.25 & 6 & 0.62 \\
\hline Early Dinner & 121 & 12.60 & 73 & 7.60 & 294 & 30.62 & 140 & 14.58 & 332 & 14.58 \\
\hline Dinner & 862 & 89.79 & 45 & 4.68 & 39 & 4.06 & 11 & 1.14 & 3 & 0.31 \\
\hline Night Meal & 45 & 4.68 & 45 & 4.68 & 206 & 21.45 & 166 & 17.29 & 498 & 51.87 \\
\hline
\end{tabular}

Table 7. The consumption frequency of some food groups by the preschool children

\begin{tabular}{|l|c|c|c|c|c|c|c|c|c|c|}
\hline \multirow{2}{*}{ Foods } & \multicolumn{2}{|c|}{ Always } & \multicolumn{2}{c|}{ Often } & \multicolumn{2}{c|}{ Sometimes } & \multicolumn{2}{c|}{ Rarely } & \multicolumn{2}{c|}{ None } \\
\cline { 2 - 12 } & $\mathbf{n}$ & $\mathbf{\%}$ & $\mathbf{n}$ & $\mathbf{\%}$ & $\mathbf{n}$ & $\mathbf{\%}$ & $\mathbf{n}$ & $\mathbf{\%}$ & $\mathbf{n}$ & \% \\
\hline Milk, Yogurt, Ayran, Cheese & 623 & 64.89 & 190 & 19.79 & 102 & 10.62 & 30 & 3.12 & 15 & 1.56 \\
\hline Fruit yogurt & 107 & 11.14 & 86 & 8.95 & 245 & 25.52 & 182 & 18.95 & 340 & 35.41 \\
\hline Meat, Chicken, Fish,Turkey & 438 & 45.62 & 232 & 24.16 & 227 & 23.64 & 38 & 3.95 & 25 & 2.60 \\
\hline Egg & 595 & 61.97 & 159 & 16.56 & 157 & 16.35 & 24 & 2.50 & 25 & 2.60 \\
\hline Pizza, Hamburger & 30 & 3.12 & 44 & 4.58 & 263 & 27.39 & 215 & 22.39 & 408 & 42.50 \\
\hline Sausage, Salami, Sausage etc., & 27 & 2.81 & 46 & 4.79 & 262 & 27.29 & 220 & 22.91 & 405 & 42.18 \\
\hline Homemade sandwich & 152 & 15.83 & 158 & 16.45 & 300 & 31.25 & 141 & 14.68 & 209 & 21.77 \\
\hline Fruit and vegetable & 616 & 64.16 & 195 & 20.31 & 120 & 12.5 & 14 & 1.45 & 15 & 1.56 \\
\hline Prepared fruit juice & 304 & 31.66 & 217 & 22.60 & 308 & 32.08 & 86 & 8.95 & 45 & 4.68 \\
\hline Herbal teas & 22 & 2.29 & 25 & 2.60 & 114 & 11.87 & 121 & 12.60 & 678 & 70.62 \\
\hline Coffee, Tea & 94 & 9.79 & 70 & 7.29 & 278 & 28.95 & 242 & 25.20 & 276 & 28.75 \\
\hline Nuts & 187 & 19.47 & 216 & 22.5 & 362 & 37.70 & 163 & 16.97 & 32 & 3.33 \\
\hline Legumes & 305 & 31.77 & 178 & 18.54 & 273 & 28.43 & 96 & 10 & 108 & 11.25 \\
\hline Pastry work, Biscuit etc., & 164 & 17.08 & 192 & 20 & 499 & 51.97 & 93 & 9.68 & 12 & 1.25 \\
\hline Oats,cornflakes, etc., & 31 & 3.22 & 34 & 3.54 & 135 & 14.06 & 157 & 16.35 & 603 & 62.81 \\
\hline Chips, Popcorn & 125 & 13.02 & 114 & 11.87 & 367 & 38.22 & 280 & 29.16 & 74 & 7.70 \\
\hline Breadsticks, Melba toast & 5 & 0.52 & 12 & 1.25 & 57 & 5.93 & 116 & 12.08 & 770 & 80.20 \\
\hline Chocolate & 158 & 16.45 & 142 & 14.79 & 545 & 56.77 & 93 & 9.68 & 22 & 2.29 \\
\hline Pudding, Ice Cream, Desserts etc., & 79 & 8.22 & 99 & 10.31 & 489 & 50.93 & 242 & 25.20 & 51 & 5.31 \\
\hline Cola drinks, Powder drinks etc., & 47 & 4.89 & 39 & 4.06 & 241 & 25.10 & 313 & 32.60 & 320 & 33.33 \\
\hline Sugar, Confectionery & 116 & 12.08 & 143 & 14.89 & 382 & 39.79 & 242 & 25.20 & 77 & 8.02 \\
\hline
\end{tabular}


The physical development of the body shows variations according to age and affects the developmental stages of height as well as the weight of individuals, and the development of the organs that make up the body (Erkan and Akyol, 2018). In order to have a healthy life, it is necessary to keep a balance between the energy consumed and the energy taken in (Essah et al., 2014). Today, the greatest problem of undeveloped countries is hunger and famine. In this study, the nutritional status and physical development of children aged 4-6 years are discussed.

There were no statistically significant differences in terms of the relation between the BMI and gender of the children $(P>0.05)$. In a study in which the obesity prevalence among children living in the United States and in our country was reported, it was determined that there was a similar distribution between girls and boys; and there was no significant difference between the BMI (Kondolot et al., 2011; Ogden et al., 2014).

Although the BMIs of the children were not related to fathers' BMI, there was a correlation between mothers' BMI at $r=0.158$. Although this relation was wasting, it is possible to claim that in the case where maternal BMI was increased, there is also an increase in the BMIs of the children. Similar results were reported in a study investigating the factors that affect obesity formation (Ulutaş et al., 2014).

When the correlation parameters were examined, a wasting effect was determined $(\mathrm{r}=0.163)$ of fathers' education status $(\mathrm{r}=0.121)$, occupations $(\mathrm{r}=0.001)$, family social security status $(r=0.096)$, the total monthly income of the family $(\mathrm{r}=0.166)$, the monthly expenditures of the children $(r=0.160)$, and the residential areas $(r=0.018)$ on the BMI of the children; and it was also observed that the education, parents' professions and the income level of families affected the children's BMI values as much as the opportunities offered to the children. Previous studies also reported that maternal education has positive effects on children's education and development (Rowe et al., 2016). In this respect, it was also determined that especially in the provinces where the income of the families was higher (Bitlis/Center and Tatvan) there ware increases in the number of fat and obese children; and it increased significantly compared to other counties $(P<0.05)$.

Although there was no significant difference between the BMIs of the children and how they traveled to schools (service buses provided by the Ministry of National education/private vehicles), there are data showing that facilitated transportation improves obesity (Kimm et al., 1996).
Although there was no statistically significant difference between the BMIs of the children and the total number of siblings in families and the working status of the parents, this situation might have stemmed from the fact that very few of the mothers who participated in our study worked $10.6 \%$ (101); and very few of the fathers $0.8 \%$ (7) did not work. This can be examined in a more comprehensive study.

There was a moderate correlation between the BMI values and the sleep durations of the children $(\mathrm{r}=0.54)$. There are similar studies in which fatness and obesity were reported to increase as well as the increase in sleep durations (Sancak et al., 1999). The fact that children spend a certain amount of time by sleeping which may be spent with other activities and that the metabolism works in a lower level during sleep might have been influential in this outcome.

It was determined that there was no difference in the meals of the children and their BMI according to the income level of the families;

- The answers given in general to the question on the frequency of consumption of the three main meals of the day (breakfast, lunch, dinner) were "always" or "often".

- While the consumption of brunch was answered as "sometimes" and "never"; there were answers showing that the afternoon and night snacks were consumed "frequently" or "sometimes".

Snacks like brunch are the mostly skipped snack. It is known that afternoon snacks and night snacks are preferred relatively more (Al-Bashtawy, 2017). It should be noted that although these data on meals seem interesting, it must be kept in mind that the amount of food consumed during meals will affect the BMI rather than the frequency of meals.

The total monthly incomes of the families and the BMI of the children did not differ significantly;

- The consumption frequency of foods such as milk, ayran, yogurt, cheese, fruit, vegetables, meat, fish, chicken, turkey and eggs were "always" and "often",

- The consumption frequency of legumes, ready-made fruit juice, and chocolate consumption frequency was "always" and "sometimes",

- The frequency of consuming pastries, biscuits, and nuts was "often" and "sometimes",

- The frequency of consuming pudding, ice cream, sweets and candies, crisps and popcorn was "sometimes" and "rarely", 
- The frequency of consumption of home-made sandwiches was "sometimes" and "none",

- The frequency of consumption of cokes, drink powders, grissini, melba toast, herbal teas, coffee, tea, oats, cornflakes etc. was distributed between "rarely" and "none", as shown in Table 7.

It was determined that there was a significant difference $(P<0.05)$ between the total monthly incomes of the families and the BMIs of the children; and in terms of correlation relations, it was determined that there was a very high relation between the use of some food types such as fruit yogurt $(\mathrm{r}=0.87)$, pizza, hamburger $(\mathrm{r}=0.90)$, sausage, salami, etc. $(\mathrm{r}=0.89)$. In this respect, while the consumption frequency of these foods was "high" and "occasionally" in families with high socio-economic status, the frequency of this consumption in children with families that had lower socio-economic status was "rarely" and "never". Similar results were found in a study on socioeconomic status and obesity (Sisson et al., 2017) and in another study on the consumption of such foods (Savaşhan et al., 2015).

In the food groups that are necessary for children, the inclusion of foods such as milk, ayran, yogurt, cheese, fruit, vegetables, meat, fish, chicken, turkey, egg, legumes, and nuts in meals, and children from almost any background consuming them is a good sign. However, ready-made fruit juice, chocolate, pastries, biscuits, pudding, ice cream, sweets and candies, crisps and popcorn, cokes, drink powder, etc. are nutrients that are easily accessible today, and in long-term use, they may give rise to all kinds of health problems and diseases, especially obesity not only in children but also in young people and in adults (TUBER, 2015; Kirılan et al., 2005; Iş1k et al., 2013).

The amount and the diversity of nutrients that are available for children are increasing in direct proportion with the high income levels (Kazak et al., 2015). It may be claimed that depending on the increase in income levels, the BMI of children increase and cause the consumption of high-calorie but unhealthy fruits such as yogurt, pizza, hamburger, sausage, salami, etc., the foods in this group are prepared especially in industrial environments, and are processed, and contain too many simple sugars or trans fats. Similarly, it is evident that such foods increase the BMI values, fatness and obesity as well as several health problems.

\section{Conclusion}

Our findings showed that nutrition and physical development of children was associated positively with a weak correlation with the socio-economic and educational levels of the parents; and was associated positively with a very high correlation with the consumption of certain food groups.

\section{Compliance with Ethical Standard}

Conflict of interests: The authors declare that for this article they have no actual, potential or perceived the conflict of interests.

Ethics committee approval: The study protocol was approved by Bitlis Eren University, Ethical Principles and Ethics Committee decision dated 13.12.2017 and with the number 2017/12-V.

Acknowledgment: This work is a graduate study and was carried out at Bitlis Eren University Institute of Science, Department of Disciplinary Disaster Management.

\section{References}

Acharya, J., van Teijlingen, E., Murphy, J., Hind, M. (2015). Study on nutritional problems in preschool aged children of Kaski district of Nepal. Journal of Multidisciplinary Research in Healthcare, 1(2), 97-118.

Aksoy, A., Selen, H. (2018). The evaluation of body composition and anthropometric measurements of males aged 18-25 years, based on the regularity of physical exercise. Progress in Nutrition, 20(3), 338-343.

Aksoy, A., Selen, H., Ozdemir, F.A., Bulut Arıkan, F. (2017). Association of physical activity and obesity status for individuals between the ages of 18-30 via bioelectrical impedance analysis device and metabolic holter measurements. Progress in Nutrition, 19(4), 391-397.

Aktaş, N., Angın, D.E. (2011). Nutrition education and food services in preschool education institution: spain and turkey. Revista Espanola de Nutricion ComunitariaSpanish Journal of Community Nutrition, 17(1), 6-12.

Al-Bashtawy, M. (2017). Breakfast eating habits among schoolchildren. Journal of Pediatric Nursing, 36, 118-123.

American Academy of Pediatrics (AAP). 2018. About Childhood Obesity. Institute for Healthly Childhood Weight. http://www.aap.org/obesity/about.html (accessed 13.08.2018).

Angın, E., Aktaş, N., Cebirbay, M.A. (2015). A nutrition guide for early childhood active stakeholders. INES Uluslararası Eğitim Bilimleri Dergisi, 2(4), 419-426. 
Auestad, N., Hurley, J.S., Fulgoni, V.L. Schweitzer, C.M. (2015). Contribution of food groups to energy and nutrient intakes in five developed countries.

Nutrients, 7(6), 4593-618.

Demirtaş, B. (2008). Doğu ve güneydoğu anadolu bölgelerinde eğitim ve öğretim (1923-1938). Atatürk Yolu Dergisi, 41, 63-87.

Ekinci, G.M. (2018). Okul öncesi çocuklarda beslenme. Ekonomi ve KültürAyrıntı Dergisi, 5(59), 27.

Erkan, S., Akyol, T. (2017). A study on the views of preschool teachers and teacher candidates about the concepts of learning and participation. Educational Research and Reviews, 12(6), 373-379.

Essah, E.A., Ofetotse, E.L. (2014). Energy supply, consumption and access dynamics in botswana. Sustainable Cities and Society, 12, 76-84.

Forno, E., Han, Y.Y., Libman I.M., Muzumdar, R.H., Celedon, J.C. (2018). Adiposity and asthma in a nationwide study of children and adults in the United States. Annals of the American Thoracic Society, 15(3), 322330.

Garipağaoğlu, M., Özgüneş, N. (2008). Okullarda beslenme uygulamaları. Çocuk Dergisi, 8(3), 152-159.

Hashemian-Nejad, N., Pejhan, A., Rakhshani, M.H., Hoseini, BL. (2014). The incidence of low birth weight (LBW) and small-forgestational age (SGA) and its related factors in neonates, sabzevar, Iran. International Journal of Pediatrics (Supplement 6), 2(4), 73-78.

Hwalla, N., Al Dhaheri, A.S., Radwan, H., Alfawaz, H.A., Fouda, M.A., Al-Daghri, N.M., Zaghloul, S., Blumberg, J.B. (2017). The prevalence of micronutrient deficiencies and inadequacies in the middle east and approaches to interventions. Nutrients, 9(3), E229.

Iş1k, H., Dağhan, Ş., Gökmen, S. (2013). G1da endüstrisinde kullanılan yenilebilir kaplamalar üzerine bir araştırma. Gıda Teknolojileri Elektronik Dergisi, 8(1), 26-35.

Kazak, A.E., Schneider, S., Didonato, S., Pai, A.L. (2015). Family psychosocial risk screening guided by the pediatric psychosocial preventative health model (PPPHM) using the psychosocial assessment tool (PAT). Acta Oncologica, 54(5), 574-80.

Kıralan, M., Yorulmaz, A., Ercoşkun, H. (2005). Trans yağ asitler, kaynakları ve insan sağlığı üzerine etkileri. Gıda ve Yem Bilimi Teknolojisi, 7, 52-64.

Kimm, S.Y., Obarzanek, E., Barton, B.A., Aston, C.E., Similo, S.L., Morrison, J.A., Sabry, Z.I., Schreiber, G.B., McMahon, R.P. (1996). Race, socioeconomic status, and obesity in 9- to 10- year-old girls: the NHLBI growth and health study. Annals of Epidemiology, 6, 266-75.

Kondolot, M., Balcı, E., Öztürk, A., Mazıcıŏglu, M.M., Hatipoğlu, N., Kurtoğlu, S., Üstünbaş, B.H. (2011). Body mass index percentiles for turkish children aged 0-84 months. Annals of Human Biology, 38(6), 676680.

Ogden, C.L., Carroll, M.D., Kit, B.K. (2014). Prevalence of childhood and adult obesity in the United States, 20112. Journal of the American Medical Association, 311(8), 806-814.

Özmert, E.N., Yurdakök, K., Soysal, S, Kayıkçı, M.E., Belgin, E., Özmert, E., Laleli, Y., Saraçbası, O. (2005). Relationship between physical, environmental and sociodemographic factors and school performance in primary school children. Journal of Tropical Pediatrics, 51(1), 25-32.

Prado, E.L., Dewey, K.G. (2014). Nutrition and brain development in early life. Nutrition Reviews, 72(4), 267-284.

Rowe, M.L., Denmark, N., Harden, B.J., Stapleton, L.M. (2016). The role of parent education and parenting knowledge in children's language and literacy skills among white, black, and latino families. Infant and Child Development, 25(2), 198-220.

Sancak, R., Dündar, C., Totan, M., Çakır, M., Sunter, T., Küçüködük, Ş. (1999). Ortaokul ve lise öğrencilerinde obezite prevalansi ve predispozan faktörler. Ondokuz Mayıs Üniversitesi Tip Dergisi, 16(1), 19-24.

SEGE (2013). Illerin ve Bölgelerin Sosyo-Ekonomik Gelişmişlik Sıralaması. Kalkınma Bakanlığı, Bölgesel Gelişme ve Yapısal Uyum Genel Müdürlüğü $S E G E$ 2011 (p. 50), Ankara. 
Shloim, N., Edelson, L.R., Martin, N., Hetherington, M.M. (2015). Parenting styles, feeding styles, feeding practices, and weight status in 4-12 year-old children: a systematic review of the literature. Frontiers in Psychology, 14(6), 18-49.

Sisson, S.B., Kiger, A.C., Anundson, K.C., Rasbold, A.H., Krampe, M., Campbell, J., DeGrace, B., Hoffman, L. (2017). Differences in preschoolage children's dietary intake between meals consumed at childcare and at home. Preventive Medicine Reports, 8(6), 33-37.

Şavaşhan, Ç., Sarı, O., Aydoğan, Ü., Erdal, M. (2015). İlköğretim çağındakı çocuklarda obezite prevalansinin belirlenmesi ve risk faktörlerinin araştırılması. Türkiye Aile Hekimliği Dergisi, 19(1), 2-9.

Tam, A.A., Çakır, B. (2012). Birinci basamakta obeziteye yaklaşım. Ankara Medical Journal, 12(1), 37-41.

TBSA. (2010). Türkiye Beslenme ve Sağlık Araştırması. (p, 139-144), Ankara.

http://ekutuphane.sagem.gov.tr/kita-

plar/turkiye beslenme_ve_saglik_arastir-

masi_tbsa)_2010 saha uygula-

masi_el kitabi.pdf (accessed 25.07.2018).

TÜBER (2015). Türkiye Beslenme Rehberi. T.C. Sağlık Bakanlığ 1 , Halk Sağlığı Kurumu, Basım: Kayhan Ajans. Ankara 2016, ISBN: 978-975-590-608-9.
Uauy, R., Kain, J., Mericq, V., Rojas, J., Corvalán, C. (2008). Nutrition, child growth, and chronic disease prevention. Annals of Medicine, 40(1), 11-20.

Ulutaş, A.P., Atla, P., Say, Z.A., Sarı, E. (2014). Okul çağındaki 6-18 yaş arası obez çocuklarda obezite oluşumunu etkileyen faktörlerin araştırılması. Zeynep Kamil Tip Bülteni, 45, 192-196.

World Health Organization. (1995). Physical Status: The Use and Interpretation of Anthropometry. Technical Report Series 854, Geneva. ISBN:9241208546. http://www.who.int/childgrowth/publications/physcal_status/en/ (accesed 04.06.2018).

World Health Organization. (2000). Obesity: Preventing and Managing the Global Epidemic. Technical Report Series 894, Geneva. ISBN: 9241208945. http://www.who.int/nutrition/publications/obesity/WHO TRS 894/en/ (accesed 04.06.2018).

World Health Organization. (2006). Child Growth Standards. Length/height-for-age, weight-for-age, weightfor-length, weight-for-height and body mass index-forage Methods and development. WHO Press, $1211 \mathrm{Ge}-$ neva. $\quad$ http://www.who.int/childgrowth/standards/Technical_report.pdf(accesed 13.08.2018).

Yalvaç, S., Erkan, T., Erginöz, E., Çullu, Ç.F., Kutlu, T. (2008). Bahçelievler çocuk yuvası 0-6 yaş grubunda beslenme durumunun değerlendirilmesi. Türk Pediatri Arşivi, 43, 89-93. 